\title{
Natural Gas in Iraq, Currently and Future Prospects: A Review
}

DOI:10.36909/jer.11989

Dheyaa J. Jasim", Thamer J. Mohammed ", Mohammad F. Abid ${ }^{* *}$

*Al-Amarah University College, Department of Petroleum Engineering, Maysan, Iraq

** University of Technology, Chemical engineering Department, Baghdad, Iraq

**** Alhikma University College, Department of Medical Instrumentation Engineering, Baghdad, Iraq

*che.17.900@ student.uotechnology.edu.iq

***thamer_jasim58@yahoo.com

**** mohammad.abid@ hiuc.edu.iq

\begin{abstract}
ABSRACT
This paper aims to demonstrate the importance of natural gas as a substantial source of energy as an alternative to crude oil, with the increase in global demand for it in the future, and the importance of this source for Iraq at the economic and environmental level. This article provides an overview of Iraq's natural gas reserves and the geographical distribution of this reserve over the regions of Iraq, in addition to the companies operating and developer there. The challenges facing the export and industry of gas in Iraq, the quantities of gas that are flared annually, and the associated financial and environmental damage were also presented. Finally, if the quantities of produced gas were to be invested, Iraq would achieve a significant improvement in the economic and environmental level.
\end{abstract}

Keywords: Iraq; natural gas; gas flaring; economic; environmental 


\section{INTRODUCTION}

As an available and clean energy source, natural gas plays an important role in meeting the increasing global demand for many sectors such as power, industry, transport and other (Mesbah et al., 2019). According to International Energy Outlook 2019, global natural gas demand is expected to grow by $40 \%$ between 2018 and 2050, reaching around 200 quadrillion British thermal units (Btu) by 2050 (EIA, 2019). As for the participation of natural gas compared to other energy sources, it increased to $24 \%$ in 2018 , which is one of the fastest growth rates since 1984 as shown in Figure 1 (Spencer, 2019).

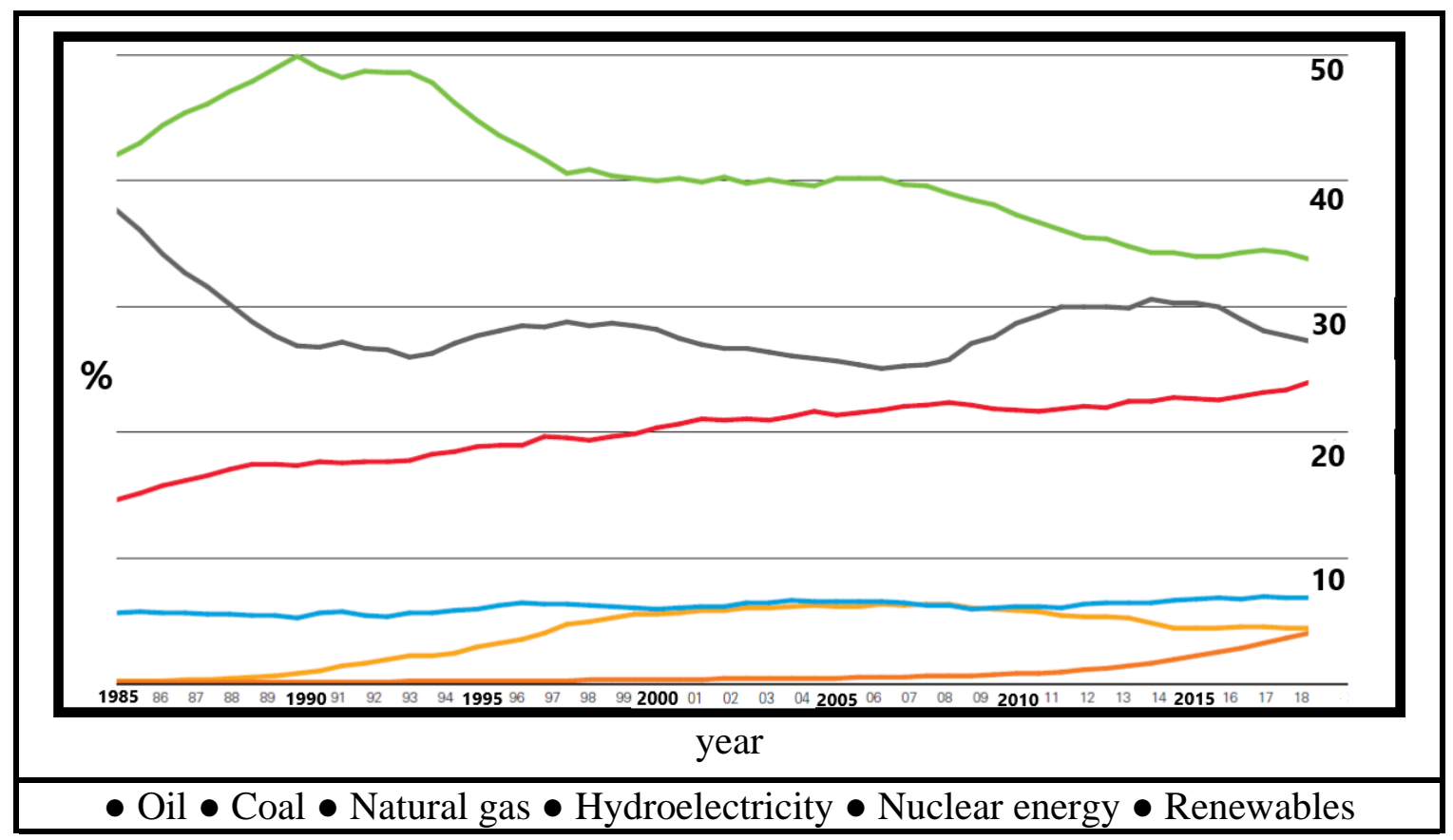

Figure 1: Shares of Global Primary Energy Consumption by Fuel.

The location, type, and depth of subterranean deposits and the geology of the area are the factors upon which the composition of gas produced from wells depends ( Ghasem \& Al-Marzouqi, 
2017). Natural gas consists mainly of methane at a ratio ranging between 75 to $90 \%$, in addition to different amounts of ethane, propane and pentane. The gas also contains harmful impurities, such as nitrogen, hydrogen, water, carbon dioxide and hydrogen sulfide (Baker \& Lokhandwala, 2008).

\section{OIL AND FINANCIAL SHOCK IN IRAQ}

Iraq has proven oil reserves of 147.2 thousand barrels, and this reserve constitutes $8.5 \%$ of the total global reserves. In addition, there is an estimated gas reserve of 125.6 trillion cubic feet, and it contributes $1.8 \%$ to the total reserve, this reserve places Iraq in the eleventh position globally (Spencer, 2019; OPEC, 2019). Iraq's energy resources are easy to extract and are located in simple onshore geographic areas that are largely unpopulated. Oil fields are distributed in different regions of Iraq, Table 1 represents Iraqi oil fields with reserves of more than one billion of crude oil, which are arranged in descending order by reserve (Keyfactsenergy, 2017; IEITI, 2017 ). The beginning of the year 2020 marks the breaking point for Iraq, with the entry of the

oil price crisis, and it warns of an economic collapse that differs from the collapse that occurred in $2014-2015$. It is evident that the economic situation this year is more fragile than previous years, through the following points:

- Unlike the previous crisis, any serviceable predictor on the current shape of the recovery is notably absent.

- In 2015, Iraq was the world's second-largest contributor to global liquids growth accounting for approximately $75 \%$ of OPEC production growth.

- Iraq's role in OPEC is also changing.

- Iraq's share of public spending has increased significantly since 2014. (Mehdi \& Al-Saffar, 2020 )

Based on the aforementioned, the government is obligated to find other sources of income. 
Table 1: Iraqi Oil Fields with Reserves of More than One Billion of Crude Oil.

\begin{tabular}{|c|c|c|c|c|c|c|c|}
\hline Field & $\begin{array}{l}\text { Reserves } \\
\text { Billion } \\
\text { barrels }\end{array}$ & Developed by & $\begin{array}{l}\text { Contract } \\
\text { Date }\end{array}$ & $\begin{array}{l}\text { Contract } \\
\text { Duration }\end{array}$ & $\begin{array}{l}\text { production } \\
\text { Target } \\
\text { Million } \\
\text { bpd }\end{array}$ & Location & Remuneration \\
\hline Rumaila & 17.7 & $\begin{array}{l}\text { BP (38\%), CNPC (37\%), Iraqi } \\
\text { state-owned South Oil Company } \\
\text { (SOC) (25\%). }\end{array}$ & 2009 & 20 years. & 2.85 & $\begin{array}{l}30^{\circ} 13^{\prime} 49.7^{\prime \prime} N \\
47^{\circ} 24^{\prime} 39.9^{\prime \prime} E\end{array}$ & $\begin{array}{c}\$ 2.00 \text { per } \\
\text { barrel of oil }\end{array}$ \\
\hline $\begin{array}{c}\text { West } \\
\text { Qurna 2 }\end{array}$ & 13 & $\begin{array}{l}\text { Lukoil (75\%), South Oil } \\
\text { Company (25\%). }\end{array}$ & 2009 & 25 years. & 1.8 & $\begin{array}{l}30^{\circ} 533^{\prime} 03.9 ” N \\
47^{\circ} 17^{\prime} 28.2{ }^{\prime} \mathrm{E}\end{array}$ & $\begin{array}{l}\$ 1.15 \text { per } \\
\text { barrel of oil }\end{array}$ \\
\hline Majnoon & 13 & $\begin{array}{l}\text { Shell (45\%); Petronas (30\%); } \\
\text { Maysan Oil Company (25\%). }\end{array}$ & 2009 & 20 years & 1.8 & $\begin{array}{l}31^{\circ} 04^{\prime} 19.6^{\prime \prime} N \\
47^{\circ} 36^{\prime} 32.3^{\prime \prime} E\end{array}$ & $\begin{array}{l}\$ 1.39 \text { per } \\
\text { barrel of oil }\end{array}$ \\
\hline $\begin{array}{c}\text { West } \\
\text { Qurna } 1\end{array}$ & 8.7 & $\begin{array}{l}\text { ExxonMobil (25\%), PetroChina } \\
(25 \%), \text { Shell (15\%), Pertamina } \\
(10 \%), \text { Oil Exploration Company } \\
(25 \%)\end{array}$ & 2009 & 20 years & 2.825 & $\begin{array}{l}31^{\circ} 01^{\prime} 55.6^{\prime \prime} N \\
47^{\circ} 18^{\prime} 00.4^{\prime \prime} E\end{array}$ & $\begin{array}{l}\$ 1.90 \text { per } \\
\text { barrel of oil }\end{array}$ \\
\hline Kirkuk & 8.7 & North Oil Company. & None & None & 0.3 & $\begin{array}{l}35^{\circ} 31^{\prime} 58.5^{\prime \prime} \mathrm{N} \\
44^{\circ} 20^{\prime} 08.5^{\prime \prime} \mathrm{E}\end{array}$ & None \\
\hline $\begin{array}{c}\text { East } \\
\text { Baghdad }\end{array}$ & 8 & Iraqi State. & None & None & None & $\begin{array}{l}33^{\circ} 21^{\prime} 09.6^{\prime \prime} N \\
44^{\circ} 38^{\prime} 54.4^{\prime \prime} E\end{array}$ & None \\
\hline $\begin{array}{c}\text { Nahr Bin } \\
\text { Umar }\end{array}$ & 6.5 & South Oil Company (SOC) & None & None & None & $\begin{array}{l}30^{\circ} 51^{\prime} 51.3^{\prime \prime} N \\
47^{\circ} 38^{\prime} 22.8^{\prime \prime} E\end{array}$ & None \\
\hline Nasiriyah & 4.4 & Ministry of Oil (Baghdad). & None & None & None & $\begin{array}{l}31^{\circ} 21^{\prime} 07.1^{\prime \prime} N \\
45^{\circ} 57^{\prime} 58.4^{\prime \prime} E\end{array}$ & None \\
\hline Halfaya & 4.1 & $\begin{array}{l}\text { CNPC (37.5\%), Total (18.75\%), } \\
\text { Petronas (18.75\%), South Oil } \\
\text { Company (25\%). }\end{array}$ & 2009 & $\begin{array}{c}20 \text { years, later } \\
\text { extended to } 30 \\
\text { years. }\end{array}$ & 0.535 & $\begin{array}{l}31^{\circ} 49^{\prime} 40.8^{\prime \prime} N \\
47^{\circ} 25^{\prime} 20.6^{\prime \prime} E\end{array}$ & $\begin{array}{c}\$ 1.40 \text { per } \\
\text { barrel of oil }\end{array}$ \\
\hline Zubair & 4 & $\begin{array}{l}\text { Eni }(32.81 \%), \text { Kogas (18.75\%), } \\
\text { Maysan Oil Company (25\%), } \\
\text { South Oil Company (23.44\%). }\end{array}$ & 2010 & $\begin{array}{c}20 \text { years, later } \\
\text { extended to } 25 \\
\text { years }\end{array}$ & 1.125 & $\begin{array}{l}30^{\circ} 23^{\prime} 24.8^{\prime \prime} N \\
47^{\circ} 38^{\prime} 17.3^{\prime \prime} E\end{array}$ & $\begin{array}{c}\$ 2.00 \text { per } \\
\text { barrel of oil }\end{array}$ \\
\hline
\end{tabular}




\begin{tabular}{|c|c|c|c|c|c|c|c|}
\hline Badra & 3 & $\begin{array}{l}\text { Gazprom (30\%), KOGAS (22.5\%), } \\
\text { Petronas (15\%), TPAO (7.5\%), } \\
\text { Iraqi state-owned Oil } \\
\text { Exploration Company (25\%). }\end{array}$ & 2009 & $\begin{array}{l}20 \text { years, with an } \\
\text { optional 5-year } \\
\text { extension }\end{array}$ & 0.17 & $\begin{array}{l}33^{\circ} 02^{\prime} 10.8^{\prime \prime} N \\
46^{\circ} 00^{\prime} 36.3^{\prime \prime} E\end{array}$ & $\begin{array}{c}\$ 5.50 \text { per } \\
\text { barrel of oil }\end{array}$ \\
\hline $\begin{array}{l}\text { Maysan } \\
\text { Oil Fields }\end{array}$ & 2.5 & $\begin{array}{l}\text { (CNOOC) (63.75\%), (TPAO) } \\
(11.25 \%), \text { Iraq Drilling Company } \\
(25 \%)\end{array}$ & 2010 & None & 0.450 & $\begin{array}{l}32^{\circ} 00^{\prime} 51.7^{\prime \prime} N \\
47^{\circ} 26^{\prime} 25.7^{\prime \prime} E\end{array}$ & $\begin{array}{c}\$ 2.30 \text { per } \\
\text { barrel of oil }\end{array}$ \\
\hline Bai Hassan & 2.078 & North Oil Company until 2014 & None & None & 0.195 & $\begin{array}{l}35^{\circ} 42^{\prime} 00.0^{\prime \prime} N \\
44^{\circ} 05^{\prime} 60.0^{\prime \prime} E\end{array}$ & None \\
\hline Ahdab & 1 & $\begin{array}{l}\text { CNPC (75\%), North Oil Company } \\
(25 \%)\end{array}$ & 2008 & 23 years & 0.140 & $\begin{array}{l}\text { Wasit } \\
\text { province, } 180 \\
\text { km south-east } \\
\text { of Baghdad } \\
\end{array}$ & $\$ 6$ per barrel \\
\hline
\end{tabular}




\section{NATURAL GAS IN IRAQ}

Iraq has estimated natural gas reserves of 112 trillion cubic meters, the 11th largest in the world according to the International Energy Agency (BGC, 2020). Most of this gas reserve consists of the associated gas by $81 \%$, while $17 \%$ represents non-associated gas, and the remainder of the total amount is the cap gas (Al-Khatteeb, 2013). Geographically, the proven Iraqi gas reserves are distributed in south, center, west and north Iraq with ratios of 71, 9, 4 and 16, respectively. South Oil Company (currently known as Basra Oil Company), Missan Oil Company, Thi Qar Oil Company (not operational during 2016, and was officially opened in 2017), Midland Oil Company, and North Oil Company are the national oil companies operating in the Oil and gas sector in Iraq. National oil companies are responsible for developing oil and gas fields in the regions where they operate (EITI, 2018). Table 2 represents gas fields in addition to all information related to it. Iraq's production of crude oil ramped up to 4,41MMbbl/d in the 2018, as a consequence of that, The APG burning is expected to reach 17.8 billion cubic meters. A study in 2018 estimated that Iraq could save $\$ 5.2$ billion over the next four years by reducing flaring and instead recovering and using the gas (Fluenta, 2019). 
Table 2: Iraqi Gas Fields.

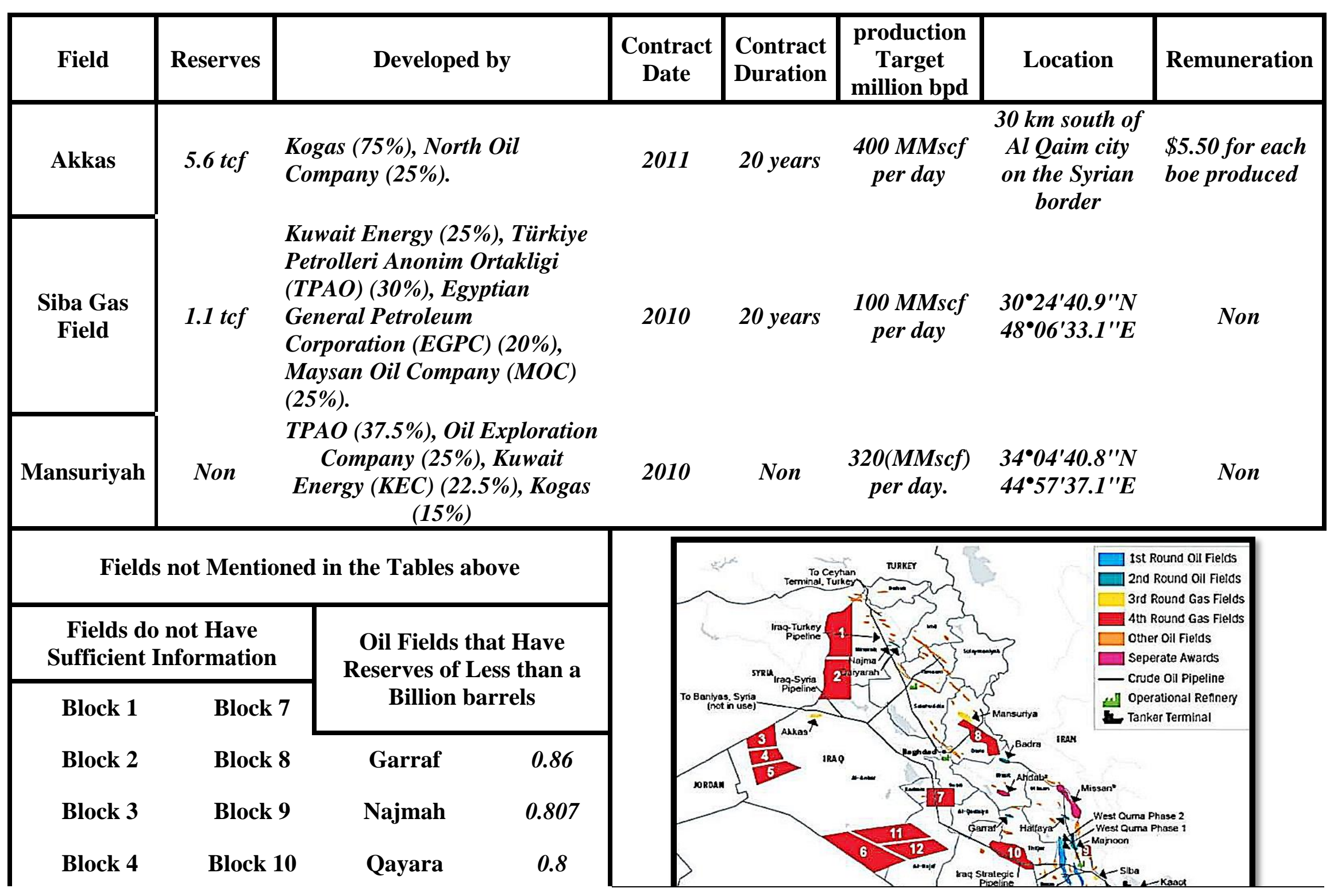


Journal of Engg. Research Online First Article

$\begin{array}{lccc}\text { Block 5 } & \text { Block 11 } & \text { Middle Furat } & 0.6 \\ \text { Block 6 } & \text { Block 12 } & \text { Eastern Fields } & \text { unknown }\end{array}$




\section{FUTURE AGEEMENTS AND ACTUAL REALITY}

Iraq's raw gas production is estimated at $2.8 \mathrm{Bcf} / \mathrm{d}$, of which $1.7 \mathrm{Bcf} / \mathrm{d}$ is being flared (50- $60 \%)$. Only approximately $1.08 \mathrm{Bcf} / \mathrm{d}$ is captured. Basra Gas Company (J.V. of SGC, Shell \& Mitsubishi) captures $0.94 \mathrm{Bcf} / \mathrm{d}$ while South Gas Company captures another $0.15 \mathrm{Bcf} / \mathrm{d}$. If flaring is minimized, Iraq's current reserves would be sufficient to supply 200 years of its current demand (Al-Maleki, 2019). The Iraqi government signed on to the World Bank's “Zero Routine Flaring by 2030" initiative in May 2017, and has been a long-standing member of the Global Gas Flaring Initiative. But past commitments to end flaring have been missed: the deadline for ending flaring in southern Iraq has already been extended from 2016 to 2022 (IEA, 2019). But until this moment, Iraq burns about 55\% of the associated gas in the fields of Basra Oil Company, Maysan Oil Company, and Al-Wasat Oil Company, according to the data of the Iraqi Oil Ministry (IMO, 2020). In return, Iraq imports gas from Iran for the purpose of generating electrical energy, and the amount is 980 million SCF / d can be increased depending on the demand for electric energy (Al-Maleki et al., 2019). Based on the assessment of the International Energy Agency and commitment to establish infrastructure, financial allocations and advance planning, the volume of gas flared could fall markedly within the next few years and drop to less than $10 \mathrm{bcm}$ in 2030 (see Figure 2). These volumes can be brought to market and lead to a much greater role for associated gas in overall gas production in Iraq (IEA, 2019). 


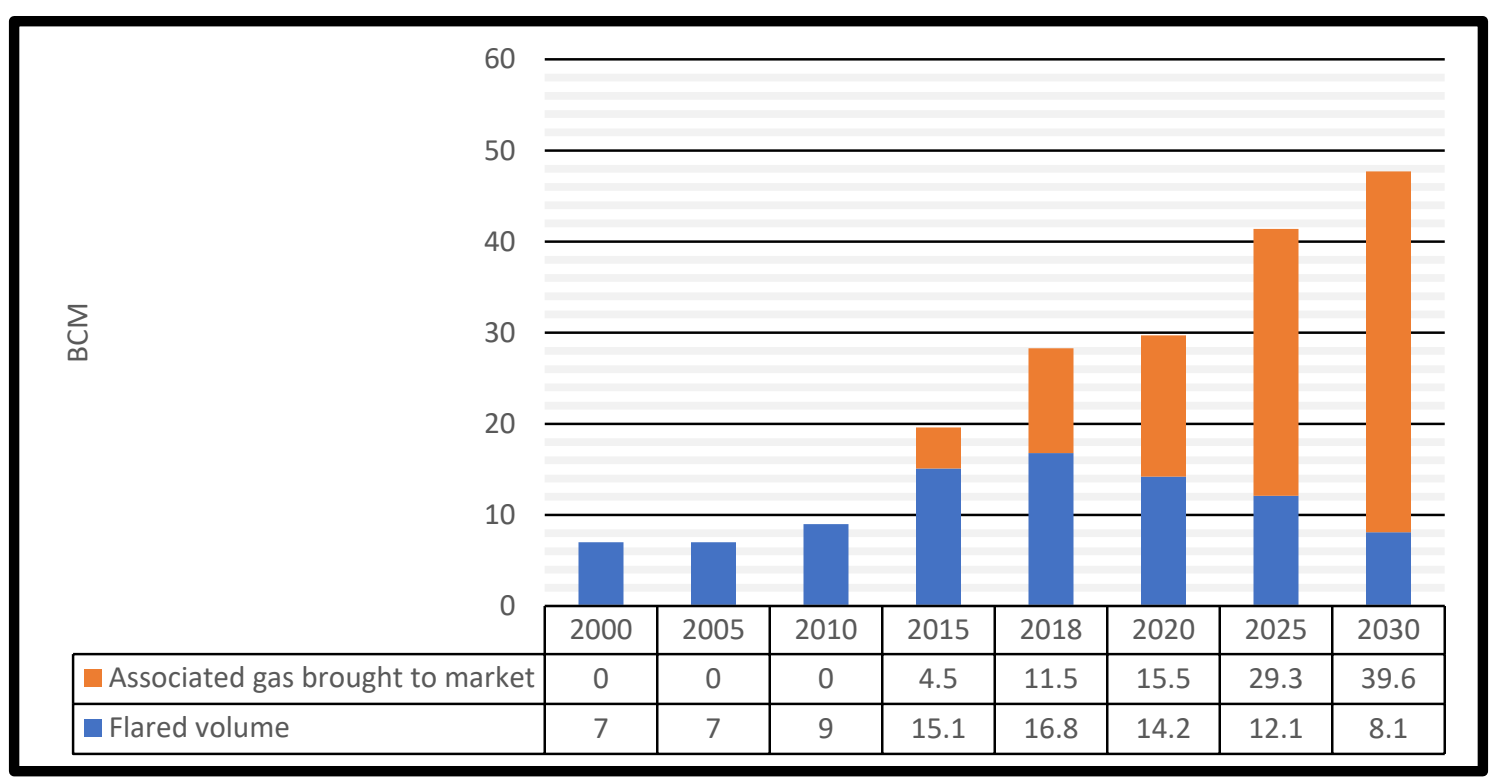

Figure 2: The International Energy Agency prediction the Future of Gas in Iraq (IEA, 2020).

\section{ENVIRONMENTAL AND HUMAN IMPACTS}

According to Offshore Energy, Iraq has the second ranking among the top flaring nations after (Russia, Iraq, Iran and the USA were the four most wasteful nations in 2018, flaring over 70 billion cubic meters of natural gas) (EcoMENA, 2020; Offshore Energy, 2020). By Check out the Global Carbon Atlas, the amount of carbon dioxide released to the atmosphere as a result of flaring gas, for Russia is 29 million tons and Iraq is 28 million tons in 2018 (Global Carbon Atlas, 2020). Figure 3 shows the carbon dioxide emissions in Iraq from 2000 to 2018. 


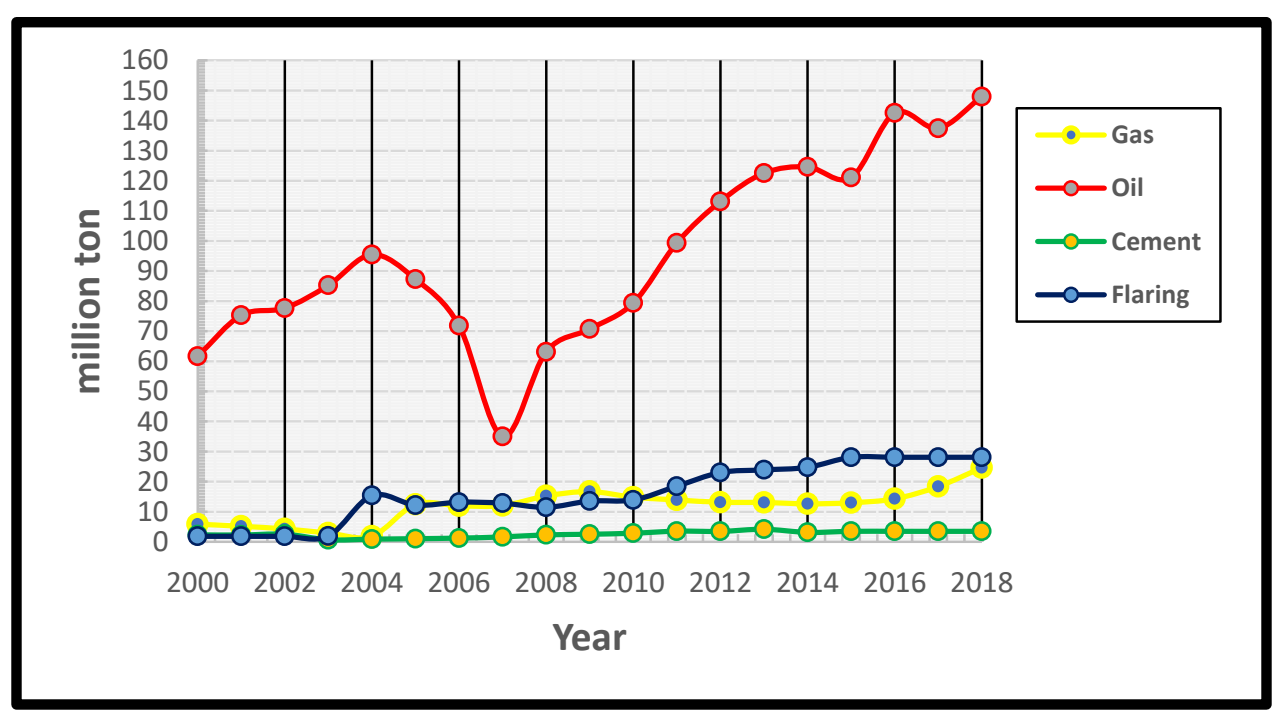

Figure 3: Carbon Dioxide Emissions in Iraq (Our World in Data, 2020).

In addition to the problems of global warming caused by the high percentage of carbon dioxide in the atmosphere, it affects humans and in the long term, with the emergence of many health problems. These include chronic infections, kidney failure, bone atrophy, loss of brain function, as well as an increased incidence of cancer (Bierwirth, 2020).

\section{CONCLUSION}

With the increase in crude oil production in Iraq, the amount of gas flared increases because most of the natural gas in Iraq is of the associated type. Which may make it in the future at the forefront of the most gas-flaring countries due to the lack of infrastructure for treatment and the inefficiency of gas collection and processing facilities. In contrast, Iraq has signed the Zero Emission Agreement with the World Bank, which is obligated to do so by 2030. In the coming years, Iraq must develop a strategy that puts an end to gas flaring, and investing this source to revive the economic situation that depends mainly on crude oil. Besides, this will lead to an improvement in the environmental and health situation in the event of reducing carbon dioxide emissions in the long term.

\section{Abbreviation \\ BGC: Basrah gas company \\ EIA: Energy International Agency}


IEITI: Iraqi Extractive Industries Transparency Initiative

IMO: Iraqi Ministry of Oil

OPEC: Organization of Petroleum Exporting Countries

\section{The biography of the authors}

\section{Thamer J. Mohammed}

- Assistant Head of the Department of Chemical Eng., University of Technology (19971999).

- Assistant Head of Department Chemical Engineering for Post Graduates, of University of Technology. (2002-2006).

- Head of Chemical Engineering Department (Dean) / University of Technology (1/7/20122/3/2017).

\section{Research Interests}

- Interested in industrial \& oily wastewater treatment.

- Interested in membrane technology uses in wastewater treatment.

- Interested in hydrodynamics characteristics in bubbly two-phase flow and in fixedfluidized beds.

2. Mohammad F. Abid

- Got PhD degree in chemical engineering in 2002 from the University of Technology in Baghdad. In 2015 he received the title of Professor in chemical engineering.

- Head of Unit Operation Branch (2006-2012).

- Head of Industrial and Petroleum Pollution Engineering Branch (2015-2017).

- Head of Pilot Research's Unit (2014- 2017)

Research Interests.

- Hydrodynamics and kinetics of multiphase catalytic reactors.

- Wastewater treatment using solar photocatalysis.

3. Dheyaa J. Jasim

- M.Sc. in Chemical Engineering, University of Basra, Basra - Iraq,2012.

- PhD Student in Chemical Engineering: Technology University, Baghdad -Iraq,2018.

\section{Research Interests}


- Interested in membrane technology.

- $\mathrm{CO}_{2}$ capture from natural gas.

- Interested in neural networks and COMSOL program.

\section{REFERENCES}

Ahmed, M. \& Al-Saffar, A. 2020. Compounding crises: Iraq's oil and energy economy. The Oxford Institute for Energy Studies, July 2020, 1-16

Al-Khatteeb, L.J. 2013. Natural gas in the Republic of Iraq, Belfer Center, November 18, 2013. Available online: http: // belfercenter. ksg. harvard. Edu / publication /23639/natural_gas_in_the_republic_of_iraq.html

Al-Maleki, Y. Gas Flaring Situation In Iraq. Group of Experts on Fossil Fuel - 2nd Meeting, Amman, 28 November 2019. https://archive.unescwa.org/sites/www.unescwa.org/files/events/files/3_gas_flaring_situation_in iraq_iraq_energy_al-maleki.pdf

Al-Maleki, Y. Robert, T. \& Istepanian, H. 2019. Annual Report: Riding the Oil Markets, Iraq's Economy in Transition, Journal of Iraq Energy Institute, February 18, 2019

Baker, R. W. B. \& Lokhandwala, K. 2008. Natural Gas Processing with Membranes: An Overview. Ind. Eng. Chem. Res. 47(7), 2109-2121

Basrah Gas Company. 2020. A fuel for Iraq's future. Available online on https://www.basrahgas.com/a-fuel-for-iraqs-future

Bierwirth, P. 2020. Carbon Dioxide Toxicity and Climate Change: A Major Unapprehended Risk for Human Health. Available online: https: // www . researchgate.net/publication/311844520_Carbon_dioxide_toxicity_and_climate change_a_major_unapprehended_risk_for_human_health, May 2020, 1-22, DOI:10.13140/RG.2.2.16787.48168

Capuano, L. 2020. International Energy Outlook 2020 (IEO2020). U.S. Energy Information 
Administration. Available online on https : // www . eia . gov / outlooks/ieo/pdf/ieo2020.pdf

EcoMENA. 2020. Gas flaring in Iraq. Available online on https://www.ecomena.org/gasflaring-in-iraq/

EITI. Iraq EITI Report Oil, Gas \& Minerals 2017. Iraq EITI. 1-154. Available online on https://eiti.org/files/documents/iraq_2017_eiti_report.pdf

Fluenta. Flaring in 2019: A year in review. fluenta.com. Dec 2019

Hannah, R. \& Max, R. 2020. Iraq: CO2 Country Profile. Our World in Data. Available on line on https://ourworldindata.org/co2/country/iraq

Ghasem, N. \& Al-Marzouqi, M. 2017. Modeling and experimental study of carbon dioxide absorption in a flat sheet membrane contactor, J. Membr. Sci. Res. 3, 57-63.

Global Carbon Atlas. 2020. CO2 Emissions. Available online on http: // www. globalcarbonatlas. org/en/CO2-emissions

International Energy Agency (EIA). 2019. Iraq's Energy Sector: A Roadmap to a Brighter Future. IEA Publications. April 2019. Available online on https://www.connaissancedesenergies.org/sites/default/files/pdfactualites/Iraq_Energy_Outlook.pdf

International Energy Agency (EIA). 2019. Natural gas production and flaring in Iraq, 2000-2030. Analysis Data and statistics. 18 Nov 2019. Available online on https://www.iea.org/data-andstatistics/charts/natural-gas-production-and-flaring-in-iraq-2000-2030

Iraqi Extractive Industries Transparency Initiative. 2018. Iraqi EITI 2016 Annual report, pp. 1216. Dec. 2018. http://ieiti.org.iq/en/listing/reports-and-publications/annual-report

Iraqi Ministry of Oil website. 2020. https://oil.gov.iq/upload/2611240027.jpg

Keyfactsenergy. 2017. ENERGY COUNTRY REVIEW: Iraq. 1-15. Available online on keyfactsenergy.com 
Mesbah, M., Momeni, M., Soroush, E., Shahsavari, S. \& Galledari, S. A. 2019.Theoretical study of $\mathrm{CO} 2$ separation from $\mathrm{CO} 2 / \mathrm{CH} 4$ gaseous mixture using 2-methylpiperazine -promoted potassium carbonate through hollow fiber membrane contactor, J. Environ. Chem. Eng. 7(1): 102781. https://doi.org/10.1016/j.jece.2018.11.026

Offshore Energy. Report: \$16,4 billion worth of gas lost to flaring in 2018. September 17, 2019. Available online on https://www.offshore-energy.biz/report-164-billion-worth-of-gas-lost-toflaring-in-2018/

OPEC. Annual Statistical Bulletin: 2010-2011 editions. Ed. Alvino-Mario Fantini. 1-108 . Available online on https://dokumen.tips/download/link/annual-statistical-bulletin-20102011

Spencer, D. 2019. BP Statistical Review of World Energy Statistical Review of World," Ed. BP Stat. Rev. World Energy, 68th edition, 1-69. Available online on https://www.bp.com/content/dam/bp/business-sites/en/global/corporate/pdfs/energyeconomics/statistical-review/bp-stats-review-2019-full-report.pdf 